\title{
An Analytical Study of Determinants of Non-Performing Loans: Evidence from Non-Bank Financial Institutions (NBFIs) of Bangladesh
}

\author{
APEL MAHMOOD RIFAT ${ }^{*}$
}

\begin{abstract}
The main focus of this study is to analyze the determinants of nonperforming loan (NPL) in Non-Bank Financial Institution (NBFI) sector in Bangladesh. Both macroeconomic and firm-specific variables are tested to determine the impact on classified loan ratio. A panel data-set consisting of seven NBFI with a time-span of 12 years (2003-2014) is analyzed for this purpose. Among macroeconomic variables, GDP growth rate, inflation rate and broad money in GDP are used. To capture management ability, firm-specific variables like, loan growth, loan to asset ratio, return on asset and relative size of firm were included in the study. Results show that firm-specific factors were more significant for non-performing loan of the NBFIs. Among macroeconomic variables, money supply was found to have significant impact.
\end{abstract}

Key Words: Non-Performing Loan, Non-Bank Financial Institutions, Macroeconomic variables, Panel dataset

\section{INTRODUCTION}

Non-performing loans are those financial assets which do not generate any interest or principal repayment for the lending institution. To ensure financial sustainability, financial intermediaries are required to minimize their non-performing loans (NPLs). Proper credit analysis and mechanism can definitely reduce these bad loans. Increase in non-performing loan is often attributed to failure of credit policy of respective institutions to select the right borrower. The responsibility cannot be solely put on lending decision. Some loans may have all qualities of good loan in initiation, but over the period turn into bad ones. Macroeconomic factors, which are not in control of the institutions, may have significant impact on the non-performing loan. Determinants of NPL have been analyzed by many researchers. Both

* Lecturer, Green Business School, Green University of Bangladesh (GUB), Dhaka 
macroeconomic variables and bank-specific variables are found to be influential in NPL.

Bangladesh is a developing economy of South Asia, it continued with positive growth rate in those recent years. Country's financial system is largely based on the banking system. Non-Bank Financial Institutions came in operation in areas where banks failed to operate prudently. Though both banks and NBFIs operations are very close, there is substantial difference in risk factors for them. Banks usually lend for short-term in traditional manner, where NBFIs finance long-term loan with innovative products. Though lots of studies have been carried out to analyze NPL of banking system, this study focuses on determinants of NPL in NBFIs.

NPL has been an important issue for financial institutions and regulators. The economic and financial costs of these non-performing loans are significant. These loans negatively impact on a firm's profitability as loss of interest income. Failure to generate earning from loan and recovering principal poses threat to firm's long term sustainability. These loans also impact on the level of private investment by increasing required provision and loss accumulation in the financial system. These loans also affect private consumption by reducing loan disbursement also known as "credit crunch" caused by erosion of firm's asset and equity.

This study tried to find the determinants of NPL by focusing on NBFIs in Bangladesh. Macroeconomic variables including real GDP, inflation, stock market return, money growth were analyzed. Different firm-specific variables were also included for consideration like loan growth, risk consideration in loan to asset ratio, relative firm size in total industry, and management efficiency measured by Return on Asset (ROA).

\section{OBJECTIVES OF THE STUDY}

The general objective of the study was to find the cause of NPL of NBFIs in Bangladesh. The specific objective of this study was to find out macroeconomic or firm- specific, variables which have more impact on NBFI's NPL. This study also tried to address different issues of the NBFI sector in Bangladesh. Other objectives of the paper can be stated as follows:

- To gain theoretical understanding about Non-performing loan;

- To analyze overall Non-Bank Financial Institution sector of Bangladesh;

- To discuss rules and regulations related to classification of loan for NBFIs in Bangladesh;

- To analyze NPL and related issues, NBFI's responses to credit risk; 
- To analyze whether macroeconomic factors affect the NPL ratio for NBFIs;

- To analyze impact of firm specific lending behavior on NPL of NBFIs;

- To discuss the channel by which factors affect the NPL ratio;

- To discuss the implications of these findings from a theoretical and practical perspective.

\section{LITERATURE REVIEW}

Non- performing loans are commonly described as loans in arrear for a long period. It is known as non-performing, because the loan ceases to "perform" or generate income for the bank. Non-performing loans can be classified into different groups usually based on the "Length of overdue" of the said loans. In different countries regulations are different for classifying loan as non-performing. In most of cases, a loan is considered to be nonperforming if that loan remains in arrear for at least 90 days. Hennie (2003) defined Non-Performing Loans as those loans which were no longer generating income. It was further supported by Fofack (2005) who defined NPL as those loans for which the principal and/or interest had been left unpaid for at least ninety days.

Non-performing loan has always been an important issue for researchers. Most studies have been made based on commercials banks of different countries. To determine the root cause of NPL, researchers considered different classes of variables. Among those class macroeconomic variables, bank specific variables and regulatory framework have been vastly analyzed.

Using dynamic panel data for 75 countries, Beck, Jakubik and Piloiu (2012) showed that, real GDP growth, share prices, exchange rate, and lending interest rate significantly affected NPL ratio. GDP was found to be most influential to NPL. NPL ratio found to be inversely related to stock returns especially for countries with large stock market relative to GDP. Saba, Kauser and Azeem (2012) used the data of US banking sector from 1985 to 2010. Employing correlation and regression tests, they showed that real GDP per capita, inflation and total loan had significant impact on Nonperforming loan ratio.

Jimenez and Saurina (2005) analyzed the Spanish banking sector from 1984 to 2003. They found significant impact of GDP growth, high real interest rate and lenient credit term on NPL. Louzis, Vouldis and Metaxas (2010) used dynamic panel data method to examine the determinants of nonperforming loans in the Greek banking sector, separately for consumer loans, business loans and mortgage loans. The study showed that NPL in the Greek banking system could be explained mainly through macroeconomic variables 
like GDP, unemployment, interest rates and management quality. Among loan tended to be (NPL), mortgage loan showed the least responsive to macroeconomic variables.

Analyzing 22 advanced economies during the period 1996-2008 J. Glen and C. Mondragón-Vélez (2011) showed that, the developments of loan loss provisions are driven mainly by the business cycle measured by real GDP growth and lending rate. Using a vector auto-regression model to analyze data from 1982 to 1996 Keeton (1999) showed rapid credit growth associated with lower credit standards, contributed to higher loan losses in the US.

Hippolyte Fofack (2005) found a strong causality between nonperforming loans and, economic growth, real exchange rate appreciation, real interest rate, net interest margins and interbank loans. He used pseudo panelbased model for the data of several Sub-Saharan African countries. The relationship between NPL and ownership structure of commercial banks in Taiwan was analyzed by $\mathrm{Hu}$ et al (2006) using a panel data-set covering the period 1996-1999. The study showed that an increase in the private shareholding induces more non-performing loans manipulated by corrupt private owners. Their study also showed that bank size was negatively related to NPL rate. Using panel regression analysis Rajan and Dhal (2003) reported that terms of credit, bank size and macroeconomic conditions had significant impact on the NPL of commercial banks in India.

Espinoza and Prasad (2010) showed that lower economic growth and higher interest rates led to an increase in NPL. Using dynamic panel data over 1995-2008 of around 80 banks in the Gulf Cooperation Council countries, the study found a positive relationship between lagged credit growth and NPL. Nkusu (2011) found significant relationship between the quality of banks' loan portfolio and macro-financial vulnerabilities. The study showed that, a sharp increase in NPL triggered long-lived tailwinds that crippled macroeconomic performance from several fronts. Rodolphe Blavy and Marcos Souto (2009) found domestic and external macro-financial variables to be closely associated with banking soundness in the Mexican banking system. At the aggregate level, high external volatility and domestic interest rates were associated with higher expected default probability. Jarmo Pesola (2005) analyzed the panel data from 1980s to 2002 to show that high customer indebtedness combined with adverse macroeconomic surprise shocks to income and real interest rates cause distress in banking sector. 


\section{METHODOLOGY, DATA AND LIMITATIONS}

This section provides a detailed overview of the methodology pursued in designing and conducting the study under three broad headings: data issues, choice of variables and statistical techniques.

\subsection{Data Issues}

This study was based on secondary data from different sources. A panel data-set from seven NBFIs of Bangladesh for the period 2003 to 2014 was used in this study. For this study total asset, total loan, return on asset, ratio of Non-performing loan to total asset were collected from the balance sheet, income statement and related notes.

Data-set also included macroeconomic variables such as real GDP growth, inflation, stock market return and broad money $\left(\mathrm{M}_{2}\right)$ for the same period. Firm specific data were collected from the annual reports of respective companies. Macroeconomic variables were collected from the World Bank website and Bangladesh Bank website.

The period used for this study was subject to data availability. Earlier data about non-performing loan were not available. Bangladesh Bank now makes banks and NBFIs to disclose details about non-performing loan, provisioning and other issues. As data were not available for previous years, data-set could not be larger.

The study included seven NBFIs which were selected based on data availability, size and relative performance. As all data related to companies were collected from annual reports, best efforts were made to ensure consistency in data. Data were collected from the consolidated financial statements of NBFIs.

Some issues should be kept in mind while going through this study. This study was subject to following constraints:

- Macroeconomic variables data-set covering twelve years was small time-span to analyze economic change. To explain economic cycle effect, a longer time-span would have been better. As NPL data were not available for earlier years, time-span could not be extended.

- All firm-related data used in this study were collected from the annual report of respective companies. Some inconsistencies were found in annual report of some companies over the years. Best effort was made to maintain consistency in the data. 


\subsection{Choice of Variables}

This study intended to analyze the effects of macroeconomic and firmspecific variables on the NPL ratio of NBFIs. Non-performing loan to total loan ratio for selected NBFIs was used as dependent variable. As independent variables, both macroeconomic and firm-specific variable were used. The following macroeconomic variables were used:

$\square \quad$ GDP growth rate;

$\square \quad$ Inflation rate;

口 Broad money.

Among bank specific variables, the following were analyzed

$\square \quad$ Loan growth rate;

$\square \quad$ Loan to total asset ratio;

$\square \quad$ Relative market share of the bank;

$\square \quad$ Return on asset.

\subsection{Statistical Techniques}

For statistical analysis, Stata 10 software was used. To understand basic characteristics of data, summary statistics and correlation matrix were used. Moreover, fixed effect regression analysis was employed on panel data-set of seven NBFIs over 12 years period, from 2003 to 2014. The basic model of the current study was as follows:

$$
\operatorname{NPLR}_{\mathrm{j}, \mathrm{t}}=\mathrm{F}\left(\mathrm{E}_{\mathrm{t}}, \mathrm{F}_{\mathrm{j}, \mathrm{t}}\right)
$$

Here, NPLR ${ }_{\mathrm{j}, \mathrm{t}}=\mathrm{J}^{\text {th }}$ Firm's Non-Performing Loan to Total Loan in period $\mathrm{t} ; \mathrm{E}_{\mathrm{t}}=$ Macroeconomic Environment captured by GDP growth, Inflation, Money Supply $; \mathrm{F}_{\mathrm{j}, \mathrm{t}}=$ Firm specific variables measured by Loan growth, Loan to Asset ratio, Return on Asset and Relative size of NBFI.

The simple regression model linked the ratio of NPL to total loans and key macroeconomic and bank specific variables. The exact specification of the model was as follows:

$(\operatorname{NPLR} j, t)=\alpha+\beta 1\left(\operatorname{LG}_{j, t}\right)+\beta 2\left(\operatorname{LoA}_{j, t}\right)+\beta 3\left(\operatorname{RoA}_{j, t}\right)+\beta 4\left(\operatorname{Size}_{j, t}\right)+$ $\beta 5\left(\mathrm{GDPG}_{\mathrm{t}}\right)+\beta 6\left(\mathrm{INF}_{\mathrm{t}}\right)+\beta 7\left(\mathrm{M}_{2} \mathrm{GDP}_{\mathrm{t}}\right)+\hat{\mathrm{e}}$

Here, NPLR ${ }_{j}, t$ represented non-performing loan to total loan ratio for individual NBFIs. $L_{\mathrm{j}}, \mathrm{t}$ was the loan growth for each NBFI over the years. This was calculated by natural log of ending loan by beginning loan balance. $\operatorname{LoA}_{j, t}$ indicated the natural $\log$ of the total loan to total asset ratio. RoA $\mathrm{j}_{\mathrm{j}, \mathrm{t}}$ represented the net income after tax to total asset of the firm. SIZE j,t was the ratio of the relative market share of each NBFI's assets to total assets of NBFI sector at time $t$. 
$\mathrm{GDPG}_{\mathrm{t}}$ was the yearly growth of GDP in Bangladesh. $\mathrm{INF}_{\mathrm{t}}$ was the inflation rate of $t$ year. $\mathrm{M}_{2} \mathrm{GDP}{ }_{\mathrm{t}}$ was the ratio of broad money (M2) over GDP in $t$ year.

\section{EMPIRICAL RESULTS AND ANALYSIS}

\subsection{Summary Statistics}

From the summary statistics, data pattern was easily observable. NonPerforming Loan ratios had large range. This implied Non Performing Loan had much variation between companies. Return on Asset varied within and also between firms. Loan to Asset ratio had mean of $74.73 \%$ with relatively small standard deviation. Loan growth variation was found to be big with greater range of negative value. Relative size of company varied in small range, importantly relative size changed greatly within companies over the time-span. Inflation rate varied with a range from $5.42 \%$ to $10.71 \%$. GDP growth fluctuated in a small range. Broad money over GDP varied in small range.

TABLE 1

\begin{tabular}{|c|c|c|c|}
\hline \multicolumn{4}{|c|}{ SUMMARY STATISTICS } \\
\hline \multicolumn{2}{|c|}{ Variables } & Mean & Std. Dev. \\
\hline \multirow[t]{3}{*}{ NPL } & Overall & \multirow[t]{3}{*}{6.557325} & 7.785896 \\
\hline & Between & & 7.068153 \\
\hline & Within & & 4.157214 \\
\hline \multirow[t]{3}{*}{ ROA } & Overall & \multirow[t]{3}{*}{2.71073} & 2.18918 \\
\hline & Between & & 1.345047 \\
\hline & Within & & 1.795307 \\
\hline \multirow[t]{3}{*}{$\mathbf{L} \_\mathbf{A}$} & Overall & \multirow[t]{3}{*}{75.27739} & 10.63933 \\
\hline & Between & & 7.271622 \\
\hline & Within & & 8.205282 \\
\hline \multirow[t]{3}{*}{ LG } & Overall & \multirow[t]{3}{*}{17.1259} & 15.75173 \\
\hline & Between & & 10.20434 \\
\hline & Within & & 12.5614 \\
\hline \multirow[t]{3}{*}{ SIZE } & Overall & \multirow[t]{3}{*}{7.060953} & 4.700459 \\
\hline & Between & & 2.693048 \\
\hline & Within & & 3.975296 \\
\hline \multirow[t]{3}{*}{ GDPG } & Overall & \multirow[t]{3}{*}{5.809067} & .9122403 \\
\hline & Between & & 0 \\
\hline & Within & & .9122403 \\
\hline \multirow[t]{3}{*}{ INF } & Overall & \multirow[t]{3}{*}{7.201061} & 1.872385 \\
\hline & Between & & 0 \\
\hline & Within & & 1.872385 \\
\hline \multirow[t]{3}{*}{ M2_GDP } & Overall & \multirow[t]{3}{*}{52.19432} & 6.479984 \\
\hline & Between & & 0 \\
\hline & Within & & 6.479984 \\
\hline
\end{tabular}


From correlation matrix, we can find the relationship between variables used in this study.

TABLE 2

CORRELATION MATRIX

\begin{tabular}{|l|l|l|l|l|l|l|l|l|}
\hline & NPL & RoA & L_A & Lg & Size & Inf & GDPg & $\begin{array}{l}\text { M2_G } \\
\text { DP }\end{array}$ \\
\hline NPL & 1.0000 & & & & & & & \\
\hline RoA & -0.0344 & 1.0000 & & & & & & \\
\hline L_A & -0.3927 & -0.1773 & 1.0000 & & & & & \\
\hline Lg & -0.4668 & 0.2324 & 0.1356 & 1.0000 & & & & \\
\hline size & 0.1907 & -0.1350 & -0.0275 & 0.0140 & 1.0000 & & & \\
\hline Inf & -0.0766 & -0.0809 & 0.2071 & -0.0061 & -0.2347 & 1.0000 & & \\
\hline GDPg & -0.0614 & -0.090 & 0.2730 & 0.0027 & -0.2831 & 0.6965 & 1.0000 & \\
\hline $\begin{array}{l}\text { M2_G } \\
\text { DP }\end{array}$ & -0.1844 & 0.0296 & 0.0653 & -0.2005 & -0.3164 & 0.4550 & 0.4717 & 1.00 \\
\hline
\end{tabular}

\subsection{Fixed Effect Regression Analysis}

In this study, a fixed effect panel model was employed to identify the determinants of NPL of NBFIs. All the variables affected non-performing loan ratio in the same manner irrespective of the firm. As we can assume a common-size effect of these variables on the dependent variable fixed effect model was more appropriate than random effect model. The following Table summarize the results of the regression model which was estimated using pooled least squares with a fixed effect estimator.

TABLE 3

GENERAL FIXED EFFECT REGRESSION MODEL

\begin{tabular}{|l|c|c|c|}
\hline Variables & Coefficient & Std. Err. & Prob \\
\hline Bank specific Factors & & & \\
\hline Return on Asset & .0030159 & .2278778 & 0.989 \\
\hline Loan growth & -.1439492 & .0352803 & 0.000 \\
\hline Loan to Asset Ratio & -.0205537 & .055819 & 0.714 \\
\hline Size & .2876401 & .1123562 & 0.013 \\
\hline Macroeconomic Factors & & & 0.167 \\
\hline GDP Growth & .9132861 & .6541914 & 0.981 \\
\hline Inflation & .0072237 & .3034432 & 0.000 \\
\hline Broad Money over GDP & -.2851301 & .0770836 & \\
\hline Prob > F $=.0000$ & & & \\
\hline
\end{tabular}


In the model, the variable lg representing loan growth was found to be significantly related at 1 percent level of significance. The negative coefficient implied demand pool loan growth maintaining credit standard lowered NPL ratio.

The variable size (which represented the relative asset size of the firm) was positive at $15 \%$ significance level. This evidence, which was inconsistent with previous studies (Rajan and Dhal, 2003; Salas and Saurina, 2002 and $\mathrm{Hu}$ et al, 2006) could be interpreted to mean that large banks were not necessarily more effective in screening loan customers when compared to their smaller counterparts.

The most important macroeconomic variable-GDP growth rate was found to be insignificant to NPL ratio. Both inflation rate and GDP growth had found positive relation at insignificant level. Broad money to GDP ratio was also found to be negatively related to Non-Performing Loan ratio. This indicated expansionary monetary policy could reduce bad debt in the financial system by lowering interest rate.

\section{CONCLUSIONS AND POLOCY-IMPLICATIONS}

This study attempted to ascertain the determinants of NPL in the Bangladesh NBFI sector using a panel dataset and a fixed effect model. The study's empirical results supported the view that non-performing loan can be explained by firm-specific variables such as loan growth and loan to asset ratio. Contrary to international evidence, our results showed that large banks were not necessarily more effective in screening loan customers when compared to their smaller counterparts - since there was no significant relationship between the size of a banking institution and the level of NPL. We also found that banks which were more aggressive in the credit market were likely to incur lower NPL, which conflicted with previous studies. This was explained as cautious loan appraisal for demand pool credit growth.

Among macroeconomic variables, the study found evidence of a significant inverse relationship between broad money to GDP and nonperforming loans. This meant that expansionary monetary policy resulted in lower non-performing loans. The empirical results, however, revealed that GDP growth rate and inflation were not important determinant of NPLs in the Bangladesh financial system. 
These findings have several implications for the financial community, academicians and policy-makers, which can be discussed as follows:

- Firm specific variables are more important in explaining nonperforming loan than macroeconomic variables. This indicates bad management is responsible for increase in non-performing loan.

- GDP growth rate and inflation are found insignificant to nonperforming loan ratio. This indicates firms' credit policy can manage the macroeconomic impact of non-performing loan.

- Expansionary monetary policy is investment friendly and this helps to reduce relative size of bad loan.

- Loan growth has been negatively related to NPL, implying that firms increasing loan amount can reduce NPL ratio. Careful observation is needed as lowering credit standard for loan growth may result in opposite effect. Firms should be increasing loan amount for good borrowers with efficient credit appraisal process. Demand pool loan growth will help the financial institutions

- Non-bank financial institutions operating with high loan to asset ratio are exposed to higher credit risk and having higher NPL ratio. NBFIs should consider their optimal risk level while exposing themselves.

- Relative asset size is found insignificant to non-performing loan ratio. This implies big firms do not necessarily have better risk management mechanism.

Because of non-availability of data, yearly data for very small time-span was used in this study. Therefore, it was difficult to analyze economic cycle effect. It is expected that, with larger time-span, macroeconomic variables would provide better result.

\section{REFERENCES}

Espinoza R. A. and Prasad A. "Nonperforming Loans in the GCC Banking System and their Macroeconomic Effects" IMF Working Papers 10/224, 2010.

Fofack, Hippolyte. "Non-performing loans in sub-Saharan Africa: Causal Analysis and Macroeconomic Implications." World Bank Policy Research Working Paper No. 3769, November, 2005.

Glen J. and Mondragón-Vélez C. "Business Cycle Effects on Commercial Bank Loan Portfolio Performance in Developing Economies", International Finance Corporation, World Bank Group, 2011.

$\mathrm{Hu}$, Jin-Li, Yang Li and Yung-Ho, Chiu "Ownership and Nonperforming Loans: Evidence from Taiwan's Banks." Developing Economies, 2006. 
Jimenez, Gabriel and Jesus S. "Credit cycles, credit risk, and prudential regulation.” Banco de Espana, January, 2005.

John S. Jordan, Problem Loans at New England Banks, 1989 to 1992: Evidence of Aggressive Loan Policies.

Keeton, "Does Faster Loan Growth Lead to Higher Loan Losses?" Federal Reserve Bank of Kansas City: Economic Review, Second Quarter, 1999.

Louzis D. P., Vouldis A. T. and Metaxas V. L. "Macroeconomic and bank specific determinants of non-performing loans in Greece: a comparative study of mortgage, business and consumer loan portfolios" Working Papers 118, Bank of Greece, 2010.

Nkusu M. "Nonperforming Loans and Macrofinancial Vulnerabilities in Advanced Economies" IMF Working Paper 11/161, 2011.

Pesola, J, "The role of macroeconomic shocks in banking crises." Bank of Finland Discussion Papers 6/2001, (April 2001).

Rajan, Rajiv and Sarat C. Dhal "Non-performing Loans and Terms of Credit of Public Sector Banks in India: An Empirical Assessment." Occasional Papers, 24:3, pp. 81-121, Reserve Bank of India, 2003.

Rodolphe Blavy and Marcos Souto, Estimating Default Frequencies and Macro-financial Linkages in the Mexican Banking Sector. IMF Working Paper, May 2009

Roland Beck, et.al. "Non-performing loans, What matters in addition to the economic cycle?" European Central Bank (ECB) Working Paper Series, NO 1515 / February 2013

Saba Irum, Kouser Rehana, Azeem Muhammad "Determinants of NonPerforming Loans: Case of US Banking Sector", The Romanian Economic Journal, June 2012.

"What Caused the Soaring Non-Performing Loans in Taiwan from the Late 1990s to the Beginning of 2000s? Evidence from Panel Data of Domestic" Banks International Journal of Information and Management Sciences, 21 (2010), 227-246 


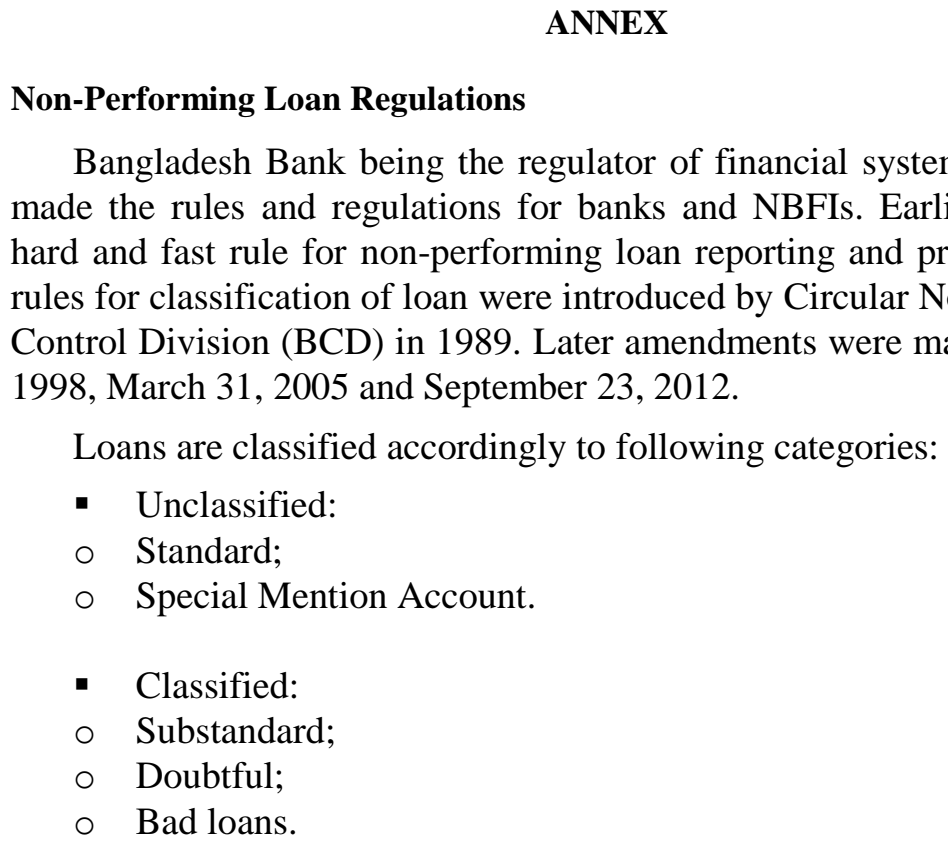
1998, March 31, 2005 and September 23, 2012.

Loans are classified accordingly to following categories:

- Unclassified:

- Standard;

- Special Mention Account.

- Classified:

- Substandard;

- Doubtful;

- Bad loans.

Bangladesh Bank being the regulator of financial system in Bangladesh made the rules and regulations for banks and NBFIs. Earlier there was no hard and fast rule for non-performing loan reporting and provisioning. First rules for classification of loan were introduced by Circular No. 34 of Banking Control Division (BCD) in 1989. Later amendments were made in December

NBFI's have to maintain provision at the following rates in respect of classified: Continuous, Demand and Fixed Term Loans:

(1) Sub-standard: 20\%;

(2) Doubtful: 50\%;

(3) Bad/Loss: $100 \%$.

Bangladesh Bank continually improved rules according to need. For keeping these in accordance with international norms NPL regulations were updated. Initially loans over-due by six months and more were considered as classified loan. Afterward, to match the classification criteria in line with international norms, the time limit was reduced to three months.

According to the circular of BCD on March 31, 2005, a Continuous credit, Demand loan or a Term loan remaining overdue for a period of 90 days or more, were put into the "Special Mention Account" and interest accrued on such loan were credited to Interest Suspense Account, instead of crediting the same to Income Account.

According to the circular effective from September 23, 2012, a Continuous loan, Demand loan or a Term Loan which will remain overdue for a period of 02 (two) months or more, will be put into the "Special Mention Account (SMA)". This will help banks to look at accounts with potential problems in a focused manner and it will capture early warning signals for accounts showing first sign of weakness. Loans overdue for 3 
months or beyond but less than 6 months is classified as 'Sub-standard' Loan. Loans overdue for 6 months to 9 months is included in 'Doubtful' loan class and loans overdue beyond 9 months is included in 'Bad/Loss'.

Loans in the "Special Mention Account (SMA)" will have to be reported to the Credit Information Bureau (CIB) of Bangladesh Bank. Loans in the "Special Mention Account" will not be treated as defaulted loan for the purpose of section $27 \mathrm{KaKa}$ (3) of the Banking Companies Act, 1991. 